\title{
Ludwigite-group minerals and szaibelyite: rare borate minerals from Vysoká - Zlatno skarn, Štiavnica stratovolcano, Slovakia
}

\author{
Vladimír Bilohuščin, Pavel Uher \\ Comenius University, Department of Mineralogy and Petrology; Ilkovičova 6, 84215 Bratislava, Slovakia; \\ e-mail:v.bilohuscin@gmail.com
}

(C) 2016 Authors. This is an open access publication, which can be used, distributed and reproduced in any medium according to the Creative Commons CC-BY 4.0 License requiring that the original work has been properly cited.

Beside of sedimentary evaporitic rocks, borate minerals occur also in some high temperature contact-metamorphic rocks, especially in skarns, locally in association with $\mathrm{Fe}$ and $\mathrm{Sn}$ ore minerals (e.g., Anovitz \& Grew 1996). The borate minerals are generally associated with the post-magmatic processes which occur in the contact aureoles of intrusive, acid to intermediary, calc-alkaline rocks (Pertsev 1991). Borate minerals of the ludwigite group and szaibelyite were identified from the Mg-skarn in the R-20 drilling core in depth of $1172 \mathrm{~m}$ during geological exploration for $\mathrm{Cu}$ Au porphyry-skarn ores in the Vysoká - Zlatno area near Banská Štiavnica, in the Štiavnica Neogene stratovolcano, central Slovakia (Koděra et al. 2010).

Ludwigite-group minerals (LGM) form massive black aggregates ( $>5 \mathrm{~cm}$ large) of numerous acicular, euhedral to subhedral prismatic crystals (usually $0.2-3 \mathrm{~mm}$ long). Ludwigite associates with clinohumite, szaibelyite, clinochlore, serpentine-group mineral, magnesite, dolomite, hematite, rarely valeriite, chalcopyrite, and sphalerite. Under transmitted light, LGM crystals are mostly opaque; locally they are translucent with strong pleochroism in sections parallel to Z-axis (deep green - dark reddish brown). In BSE, LGM crystals show regular concentric, rarely oscillatory or irregular zoning caused by distinct element variations during their growth or partial alteration: the dark zones show enrichment in $\mathrm{Mg}, \mathrm{Al}$ and $\mathrm{Ti}$, in contrast to the pale zones which reveal larger amounts of Fe. The electron-microprobe analyses reveal growth evolution of LGM crystals from Alrich azoproite with $\leq 79$ mol.\% of $\mathrm{Mg}_{2}\left(\mathrm{Mg}_{0.5} \mathrm{Ti}_{0.5}\right)$ $\left(\mathrm{BO}_{3}\right) \mathrm{O}_{2}$ end-member] to $\mathrm{Al} \pm$ Ti-rich ludwigite and Al-dominant LGM phase ["aluminoludwigite" with $\leq 53 \mathrm{~mol} . \%$ of $\mathrm{Mg}_{2} \mathrm{Al}\left(\mathrm{BO}_{3}\right) \mathrm{O}_{2}$ end-member] in central zones, whereas rim zones of the crystals and secondary veinlets attain nearly pure ludwigite composition [87-99 mol.\% of $\mathrm{Mg}_{2} \mathrm{Fe}^{3+}\left(\mathrm{BO}_{3}\right) \mathrm{O}_{2}$ end-member]. Consequently, LGM from the $\mathrm{Vy}$ soká - Zlatno skarn show the largest compositional variations ever known from one occurrence and they reach the highest contents of $\mathrm{Ti}(\leq 17.4 \mathrm{wt} . \%$ $\left.\mathrm{TiO}_{2}, 0.39 a p f u\right)$ and $\mathrm{Al}\left(\leq 14.4\right.$ wt.\% $\mathrm{Al}_{2} \mathrm{O}_{3}, 0.53$ apfu) ever reported in LGM (Schaller \& Vlisidis 1961, Marincea 2000, Pertsev et al. 2004, Aleksandrov \& Troneva 2008, 2011).

The compositional variations indicate the following substitution mechanisms in the studied LGM: $\mathrm{Mg}^{2+}=\mathrm{Fe}^{2+}$ for the all compositions, $\mathrm{Fe}^{3+}=$ $\mathrm{Al}^{3+}$ for samples without higher amount of $\mathrm{Ti}$, and $2 \mathrm{Al}=\mathrm{Mg}^{2+}+\mathrm{Ti}^{4+}$ or $2 \mathrm{Fe}^{3+}=\mathrm{Mg}^{2+}+\mathrm{Ti}^{4+}$ for analyses including high $\mathrm{Ti}$ content.

Szaibelyite $\mathrm{MgBO}_{2}(\mathrm{OH})$ occurs as aggregates of fibrous crystals, up to $0.5 \mathrm{~mm}$ in size, replacing LGM. Zoning in szaibelyite was not observed. The amounts of $\mathrm{Mg}$ are uniform (0.98 to $0.99 \mathrm{apfu}$ ), content of $\mathrm{Fe}^{2+}$ oscillates from 0.2 to $1.2 \mathrm{wt} . \% \mathrm{FeO}$ (0.002-0.014 apfu) and indicates the $\mathrm{Mg}^{2+}=\mathrm{Fe}^{2+}$ substitution. Szaibelyite also contains small admixtures of $\mathrm{Mn}$ (0.1-0.4 wt.\% $\mathrm{MnO}$ ), $\mathrm{Al}$ and $\mathrm{Cr}$ ( $\leq 0.3$ wt. $\% \mathrm{Al}_{2} \mathrm{O}_{3}$ or $\mathrm{Cr}_{2} \mathrm{O}_{3}$ ).

The skarn mineralization originated as a result of contact thermal metamorphism of Miocene 
calc-alkaline granodiorite intrusion on host Middle to Upper Triassic limestones, dolomites, shales and evaporitic anhydrite beds (the Vel'ký Bok Group, Veporicum Unit). The evaporites were most likely the primary source of boron, whereas $\mathrm{Ti}$ was probably derived from the granodiorite. Clinohumite and LGM (azoproite to Al \pm Ti-rich ludwigite and "aluminoludwigite") precipitated during the high-temperature contact metamorphic event at $\sim 700^{\circ} \mathrm{C}$ and $\leq 100 \mathrm{MPa}$, whereas the youngest Al,Ti-poor ludwigite veinlets, szaibelyite, serpentine-group mineral, clinochlore, magnesite, dolomite, hematite and probably also sulfide minerals were formed during younger, lower-temperature hydrothermal-metasomatic event.

\section{REFERENCES}

Aleksandrov S.M. \& Troneva M.A., 2008. Heterovalent isomorphism in the Magnesium-Iron Borates. Geochemistry International, 46, 800-813.
Aleksandrov S.M. \& Troneva M.A., 2011. Genesis and Composition of Endogenous Borates in the Skarns of the Eastern and Central Pyrenees. Geochemistry International, $49,802-814$.

Anovitz LM. \& Grew E.S. (eds), 1996. Boron: Mineralogy, Petrology, and Geochemistry. Reviews in Mineralogy 33, Mineralogical Society of America.

Koděra P., Lexa J. \& Fallick A.E., 2010. Formation of the Vysoká-Zlatno $\mathrm{Cu}-\mathrm{Au}$ skarn-porphyry deposit, Slovakia. Mineralium Deposita, 45, 817-843.

Marincea S., 2000. The influence of $\mathrm{Al}$ on the physical and crystallographic properties of ludwigite in three Romanian occurrences. European Journal of Mineralogy, 12, 809-823.

Persev N.N., 1991. Magnesian skarns. [in:] Aksiuk A.M., Skarns: Their Genesis and Metallogeny, Theophrastus Publications, Athens, 299-324.

Pertsev N.N., Schreyer W., Armbruster T., Bernhard H.J. \& Medenbach O., 2004. Alumino-magnesiohulsite, a new member of the hulsite group, in kotoite marble from east of Verkhoyansk, Sakha-Yakutia, Russia. European Journal of Mineralogy, 16, 151-161.

Schaller W.T., \& Vlisidis A.C., 1961. Composition of aluminian ludwigite from Crestmore, California. American Mineralogist, 46, 335-339. 